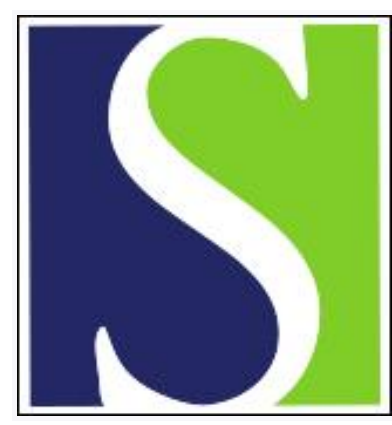

Scand J Work Environ Health 2008;34(1):73-79

https://doi.org/10.5271/sjweh.1167

Issue date: 29 Feb 2008

\title{
Cancer incidence among Finnish farmers, 1995-2005
}

by Laakkonen A, Pukkala E

Affiliation: Finnish Institute of Occupational Health, Topeliuksenkatu 41 a A, FI-00250 Helsinki, Finland. aarne.laakkonen@kolumbus.fi

Refers to the following texts of the Journal: 2004;30(3):215-222 1996;22(1):14-26 2002;28(3):158-162 1999;25 suppl 2:1-116

The following article refers to this text: 2010;36(6):515-516

Key terms: cancer; cancer incidence; epidemiology; farm type; farmer; Finland; occupation

This article in PubMed: www.ncbi.nlm.nih.gov/pubmed/18427701

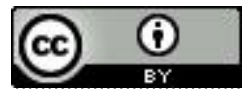




\title{
Cancer incidence among Finnish farmers, 1995-2005
}

\author{
by Aarne Laakkonen, MD, ${ }^{1}$ Eero Pukkala, PhD²
}

\author{
Laakkonen A, Pukkala E. Cancer incidence among Finnish farmers, 1995-2005. Scand J Work Environ Health. \\ 2008;34(1):73-79.
}

\begin{abstract}
Objectives The aim of this study was to describe the cancer risk pattern of male and female Finnish farmers and to define the role of the type of farm production as a risk determinant.

Methods All farmers on 31 December 1978 living on 1 January 1995 were included in the cohort. The data concerning continuation as a farmer and the type of farming was collected from the 31 December 1990 and 1994 farm registries. The observed number of cases in each stratum was divided by the respective expected number based on national incidence rates to calculate the standardized incidence ratio.

Results The overall cancer incidence was smaller than that of the general population. For most of the cancer sites, the standardized incidence ratios were below 1.0. The lowest rates for farmers continuing to farm were determined for mesothelioma and cancers of the liver, larynx, lung, nose, esophagus, and urinary bladder. The only significantly elevated standardized incidence ratio was that for lip cancer. Permanent beef and dairy farmers had the lowest standardized incidence ratios for overall cancer. Dairy farmers of 1978 who had changed their production type to crop farmers had increased their risk for overall cancer from a standardized incidence ratio of 0.82 to 0.92 .

Conclusions The cancer incidence of Finnish farmers was significantly below the national average. The finding that lung cancer risk was low among dairy farmers but increased with a change to another type of farm production gives some support to the hypothesis that endotoxin exposure may decrease cancer risk.
\end{abstract}

Key terms epidemiology; farm type; occupation.

The occupational group of farmers includes field crop and vegetable growers, market-oriented animal producers, and related workers. The tasks performed include purchasing seeds, fertilizer, and other supplies; performing farm operations; sowing, cultivating, and harvesting crops; breeding, raising, and tending animals; and maintaining farm buildings, machinery, and equipment. Farmers are one of the largest single occupational groups. There were 9.3 million people employed in agriculture (4.9\% of total workforce) in the 25 member states in the European Union (EU25) in 2005, and agriculture accounted for $1.9 \%$ of the total gross value added generated in these countries (1).

Farmers are in contact with a number of potential hazardous chemicals and biological agents, including pesticides, solvents, fuels and oils, dusts, zoonotic viruses, microbes, and fungi. Some of these factors are known or suspected carcinogens (2).

A cancer deficit of about $20 \%$ was found for the overall cancer incidence for both male and female farmers in the Nordic countries (3). Among the male farmers, the risk of lip cancer was elevated in all four countries (Denmark, Finland, Norway and Sweden), whereas almost all other types of cancer showed deficit risks. The only significantly elevated risk among women was found for multiple myeloma.

The aim of this study was to describe the cancer risk pattern of Finnish farmers and to define the role of the type of farm production as a risk determinant. A specific aim was to test the hypothesis suggested by Mastrangelo et al (4) that dairy farmers exposed to endotoxin would have a decreased lung cancer risk that would disappear if the farmers change to occupations in which exposure to microbial agents is lower.

\section{Study population and methods}

The study cohort was based on the Finnish Farm Registry, which was founded on the basis of information from the general farm census of 1969 and has been

1 Finnish Institute of Occupational Health, Helsinki, Finland.

2 Finnish Cancer Registry, Institute of Statistical and Epidemiologic Cancer Research, Helsinki, Finland.

Correspondence to: Dr Aarne Laakkonen, Finnish Institute of Occupational Health, Topeliuksenkatu 41 a A, FI-00250 Helsinki, Finland. [E-mail: aarne.laakkonen@kolumbus.fi] 
used thereafter in forming official farm statistics. All persons or corporations owning a farm of at least one hectare of cultivated land (field or garden) are included in the registry.

All persons who were farmers on 31 December 1978 and living on 1 January 1995 were included in the cohort. Information about the owner (practically all farmers) of the farm was taken from the 31 December 1978 Farm Registry, and data concerning the type of farming were collected separately from the 31 December 1977 Farm Registry (because it was not included in the 1978 registry). Only male farm owners were registered in the Farm Registry; therefore, the female farmers living on these farms and actually working as farmers were traced through the register of the Farmers' Social Insurance Institution $(5,6)$. The cohort and classification of farm type was the same as in the previous study of cancer incidence among Finnish farmers by Pukkala \& Notkola (5). Data concerning continuation as a farmer and the type of farming were collected from the 31 December 1990 and 1994 farm registries. The numbers of farmers by farm type, continuation as a farmer, age, and gender are presented in tables 1 and 2 .

The identification of the persons and the follow-up for death and emigration up to 2005 were done automatically at Statistics Finland using a unique personal identification number given to everyone residing in Finland since 1 January 1967. The follow-up for cancers through the files of the Finnish Cancer Registry was also done automatically. In our present study, the follow-up started on 1 January 1995 and ended at emigration or death or on 31 December 2005, whichever occurred first.

The numbers of observed cases and person-years at risk were counted by gender and 5-year age groups. The type of farming was classified into the following six main categories: crop, beef, dairy, pig, poultry, and other. The criteria were formed in such a way that traditional farm types in Finland were well separated,

Table 1. Number and person-years of Finnish farmers in 1978 and alive in 1995, by gender and type (production) of farm in 1978 and 1990 or 1994.

\begin{tabular}{|c|c|c|c|c|c|c|c|c|c|c|c|c|}
\hline \multirow{3}{*}{$\begin{array}{l}\text { Type of } \\
\text { production }\end{array}$} & \multicolumn{4}{|c|}{ Production 1978 a } & \multicolumn{4}{|c|}{ Production 1990 or $1994^{b}$} & \multicolumn{4}{|c|}{ Quit farming ${ }^{c}$} \\
\hline & \multicolumn{2}{|c|}{ Men } & \multicolumn{2}{|c|}{ Women } & \multicolumn{2}{|c|}{ Men } & \multicolumn{2}{|c|}{ Women } & \multicolumn{2}{|c|}{ Men } & \multicolumn{2}{|c|}{ Women } \\
\hline & N & Person-years & N & Person-years & N & Person-years & $\mathrm{N}$ & Person-years & N & Person-years & $\mathrm{N}$ & Person-years \\
\hline Crop & 18848 & 173941 & 14873 & 151239 & 9643 & 96289 & 842 & 8468 & 11480 & 98809 & 14274 & 145065 \\
\hline Beef & 387 & 3969 & 279 & 2984 & 4050 & 39992 & 575 & 5792 & 166 & 1588 & 267 & 2852 \\
\hline Dairy & 42923 & 407973 & 34771 & 363082 & 13939 & 144907 & 1042 & 10902 & 26002 & 234446 & 33553 & 350380 \\
\hline Pig & 5286 & 51605 & 4349 & 45771 & 2217 & 23418 & 94 & 994 & 2910 & 26998 & 4222 & 44418 \\
\hline Poultry & 4995 & 44848 & 4194 & 42719 & 763 & 7784 & 82 & 824 & 2992 & 24870 & 3972 & 40456 \\
\hline Other & 15095 & 129847 & 17086 & 165675 & 2413 & 23495 & 347 & 3564 & 10960 & 89600 & 16283 & 157766 \\
\hline Total & 87534 & 812183 & 75552 & 771469 & 33025 & 335885 & 2982 & 30543 & 54510 & 476309 & 72571 & 740937 \\
\hline
\end{tabular}

a All farmers of 1978 who were living on 1 January 1995.

b Farmers of 1978 who were continuing to farm in 1990 or 1994, by farm type in 1990 or 1994 , respectively.

c Farmers of 1978 who had quit farming by 1990 or1994, by farm type in 1978.

Table 2. Number of Finnish farmers in 1978 and alive in 1995, by gender and age at the start of the follow-up in 1995 and person-years (attained age) at the follow-up in 1995-2005.

\begin{tabular}{|c|c|c|c|c|c|c|c|c|c|c|c|c|}
\hline \multirow[t]{3}{*}{ Age } & \multicolumn{4}{|c|}{ Production $1978^{\text {a }}$} & \multicolumn{4}{|c|}{ Production 1990 or $1994^{b}$} & \multicolumn{4}{|c|}{ Quit farming ${ }^{c}$} \\
\hline & \multicolumn{2}{|c|}{ Men } & \multicolumn{2}{|c|}{ Women } & \multicolumn{2}{|c|}{ Men } & \multicolumn{2}{|c|}{ Women } & \multicolumn{2}{|c|}{ Men } & \multicolumn{2}{|c|}{ Women } \\
\hline & $\mathrm{N}$ & $\begin{array}{l}\text { Person- } \\
\text { years }\end{array}$ & $\mathrm{N}$ & $\begin{array}{c}\text { Person- } \\
\text { years }\end{array}$ & $\mathrm{N}$ & $\begin{array}{l}\text { Person- } \\
\text { years }\end{array}$ & $\mathrm{N}$ & $\begin{array}{l}\text { Person- } \\
\text { years }\end{array}$ & $\mathrm{N}$ & $\begin{array}{l}\text { Person- } \\
\text { years }\end{array}$ & $\mathrm{N}$ & $\begin{array}{l}\text { Person- } \\
\text { years }\end{array}$ \\
\hline$\leq 29$ years & - & - & 7 & 4 & 1 & 3 & 1 & 6 & - & - & 7 & 4 \\
\hline 30-44 years & 5587 & 21249 & 4286 & 14216 & 3959 & 14221 & 211 & 647 & 1628 & 7036 & 4075 & 13575 \\
\hline $45-59$ years & 26330 & 201167 & 29143 & 210837 & 17782 & 149352 & 1378 & 10854 & 8548 & 51814 & 27765 & 199983 \\
\hline $60-74$ years & 42079 & 388325 & 36191 & 400651 & 9817 & 143288 & 1138 & 14414 & 32262 & 245037 & 35053 & 386237 \\
\hline$\geq 75$ years & 13538 & 201443 & 5925 & 145760 & 1466 & 29020 & 254 & 4622 & 12072 & 172422 & 5671 & 141138 \\
\hline Total & 87534 & 812183 & 75552 & 771469 & 33025 & 335885 & 2982 & 30543 & 54510 & 476309 & 72571 & 740937 \\
\hline
\end{tabular}

a All Farmers of 1978 who were living on 1 January 1995.

b Farmers of 1978 who were continuing to farm in 1990 or 1994, by farm type in 1990 or1994, respectively.

c Farmers of 1978 who had quit farming by 1990 or 1994, by farm type of 1978. 
and all the mixed or atypical farms were categorized as "other farms".

The expected numbers of cases were calculated by multiplying the number of person-years in each 5-year age group by the corresponding average gender-specific cancer incidence in the overall Finnish population during the period of observation. The specific cancer types selected a priori included the cancer sites with known or suspected exceptional risk among farmers in earlier studies, as well as the other common cancer types, to give the whole picture of the cancer situation among Finnish farmers.

To calculate the standardized incidence ratio (SIR), the observed number of cases was divided by the expected number. The $95 \%$ confidence intervals $(95 \% \mathrm{CI})$ of the standardized incidence ratios were calculated on the basis of the Poisson assumption.

\section{Results}

There were 87534 men and 75552 women followed in the cohort, with total person-years of $>800000$ and $>750000$, respectively (table 2). Only 22\% ( $=36007)$ of the farmers in 1978 continued to farm in 1995. The main reason for not continuing was retirement. Twothirds of the men who had quit farming were 65 years of age or older in 1995 . Nearly all $(96 \%)$ of the female farmers had quit farming by 1995 , many of them before the age of 65 years.

During the follow-up period, altogether 19640 incident cases of cancer were found (table 3 ). The overall cancer risk was reduced in comparison with that of the general population both among those who continued to farm in the early 1990s and those who had quit farming (table 3). For most of the cancer sites, the SIR values were below 1.0. The lowest rates among the farmers who continued to farm were found for mesothelioma (SIR 0.29, 95\% CI 0.11-0.62) and cancers of the liver (SIR 0.40, 95\% CI 0.26-0.59), larynx (SIR 0.51, 95\% CI 0.30-0.79), lung (SIR 0.60, 95\% CI 0.54-0.66), nose and nasal sinuses (SIR 0.62, 95\% CI 0.17-1.58), esophagus (SIR 0.65, 95\% CI 0.44-0.91), and urinary bladder (SIR 0.69, 95\% CI 0.58-0.80). The only significantly elevated SIR was that for lip cancer (SIR 1.39, 95\% CI 1.00-1.86). The SIR values for all of these cancers were higher for the farmers who quit farming before 1990 (table 3). The only cancer that showed a markedly lower SIR value for those who quit farming was cervical cancer (SIR 0.67, 95\% CI 0.49-0.88).

Among the more homogeneous farm types (the group other was heterogeneous) and the farmers who kept the same type of farm (production), beef and dairy farmers had the lowest SIR value for overall cancer, although the rate for beef farmers was based on only 5 observed and 11 expected cases (table 4). The lowest SIR values for the dairy farmers who continued as dairy farmers were for cancers of the liver (SIR 0.32, 95\% CI 0.12-0.70), bladder (SIR 0.47, 95\% CI 0.32-0.67), breast (SIR 0.48, 95\% CI 0.24-0.85), lung (SIR 0.51, 95\% CI 0.42-0.62), and colon (SIR $0.60,95 \%$ CI $0.43-0.82$ ). The only significantly elevated SIR value was the one for lip cancer

Table 3. Observed numbers of cancer cases and standardized incidence ratios (SIR) with 95\% confidence intervals $(95 \% \mathrm{CI})$ for Finnish farmers in 1995-2005, by cancer site. (Reference population: general population of Finland).

\begin{tabular}{|c|c|c|c|c|}
\hline \multirow[t]{2}{*}{ Primary site } & \multicolumn{2}{|c|}{$\begin{array}{l}\text { Continuing farming in } \\
\text { in } 1990 \text { or } 1994 \\
(\mathrm{~N}=36007)\end{array}$} & \multicolumn{2}{|c|}{$\begin{array}{l}\text { Quit farming } \\
\text { by } 1990 \text { or } 1994 \\
(\mathrm{~N}=127081)\end{array}$} \\
\hline & $\begin{array}{l}\text { Observ- SIR } \\
\text { ed (N) }\end{array}$ & $95 \% \mathrm{Cl}$ & $\begin{array}{l}\text { Observ- SIR } \\
\text { ed (N) }\end{array}$ & $95 \% \mathrm{Cl}$ \\
\hline
\end{tabular}

All sites $a, b, c \quad 3584 \quad 0.84 \quad 0.82-0.87 \quad 16056 \quad 0.89 \quad 0.88-0.90$

Lip

Esophagus

Stomach

Small intestine

Colon

Rectum

Liver

Gallbladder, bile ducts

Pancreas

Gastrointestinal, not

otherwise specified

Nose, nasal sinuses

Larynx

Lung, bronchus

Mesothelioma

Breast

Cervix uteri

Corpus uteri

Ovary

Other female genitals

Prostate

Testis

Kidney

Bladder, ureter,

urethra ${ }^{b}$

Skin melanoma

Other skin ${ }^{c}$

Nervous system

Thyroid gland

Soft tissue

Non-Hodgkin's

lymphoma

Hodgkin's lymphoma

Multiple myeloma

Leukemia

Unspecified

Skin, basal cell

carcinomad $^{d}$

$\begin{array}{llllll}43 & 1.39 & 1.00-1.86 & 191 & 1.59 & 1.37-1.82\end{array}$

$\begin{array}{lllllll}32 & 0.65 & 0.44-0.91 & 140 & 0.85 & 0.71-0.99\end{array}$

$\begin{array}{lllllll}162 & 1.07 & 0.91-1.24 & 715 & 1.09 & 1.01-1.16\end{array}$

$\begin{array}{lllllll}10 & 0.68 & 0.33-1.24 & 41 & 0.73 & 0.52-0.99\end{array}$

$\begin{array}{lllllll}162 & 0.72 & 0.61-0.83 & 919 & 0.85 & 0.79-0.90\end{array}$

$\begin{array}{lllllll}161 & 0.94 & 0.80-1.08 & 599 & 0.87 & 0.80-0.94\end{array}$

$\begin{array}{lllllll}24 & 0.40 & 0.26-0.59 & 180 & 0.78 & 0.67-0.90\end{array}$

$\begin{array}{llllll}36 & 1.14 & 0.80-1.58 & 175 & 0.85 & 0.73-0.97\end{array}$

$\begin{array}{llllll}120 & 0.84 & 0.70-1.00 & 590 & 0.92 & 0.85\end{array}$

$\begin{array}{llllll}18 & 0.91 & 0.54-1.44 & 75 & 0.74 & 0.58-0.92\end{array}$

$\begin{array}{lllllll}4 & 0.62 & 0.17-1.58 & 21 & 0.79 & 0.49-1.21\end{array}$

$\begin{array}{lllllll}19 & 0.51 & 0.30-0.79 & 59 & 0.69 & 0.53-0.89\end{array}$

$\begin{array}{lllllll}352 & 0.60 & 0.54-0.66 & 1443 & 0.73 & 0.69-0.76\end{array}$

$\begin{array}{llllll}6 & 0.29 & 0.11-0.62 & 17 & 0.30 & 0.17-0.47\end{array}$

$\begin{array}{lllllll}64 & 0.72 & 0.55-0.91 & 1530 & 0.74 & 0.71-0.77\end{array}$

$\begin{array}{lllllll}4 & 1.48 & 0.40-3.79 & 46 & 0.67 & 0.49-0.88\end{array}$

$\begin{array}{lllllll}19 & 0.91 & 0.55-1.42 & 529 & 0.98 & 0.90-1.06\end{array}$

$\begin{array}{lllllll}10 & 0.87 & 0.42-1.59 & 310 & 1.05 & 0.93-1.16\end{array}$

$\begin{array}{llllll}3 & 0.86 & 0.18-2.50 & 72 & 0.78 & 0.61-0.97\end{array}$

$\begin{array}{lllllll}1309 & 0.98 & 0.93-1.03 & 3589 & 0.96 & 0.93-0.99\end{array}$

$\begin{array}{llllll}5 & 0.83 & 0.27-1.92 & 10 & 1.50 & 0.72-2.76\end{array}$

$\begin{array}{llllll}128 & 0.83 & 0.69-0.98 & 570 & 1.00 & 0.92-1.08\end{array}$

$\begin{array}{llllll}147 & 0.69 & 0.58-0.80 & 618 & 0.78 & 0.72-0.84\end{array}$

$\begin{array}{llllll}102 & 0.95 & 0.77-1.14 & 360 & 0.93 & 0.84-1.03\end{array}$

$\begin{array}{lllllll}121 & 0.89 & 0.74-1.05 & 723 & 0.98 & 0.91-1.05\end{array}$

$\begin{array}{lllllll}88 & 0.91 & 0.73-1.12 & 381 & 0.93 & 0.83-1.02\end{array}$

$\begin{array}{llllll}23 & 0.93 & 0.59-1.39 & 159 & 1.11 & 0.95-1.29\end{array}$

$\begin{array}{lllllll}15 & 0.67 & 0.38-1.10 & 85 & 0.89 & 0.71-1.10\end{array}$

$\begin{array}{llllll}142 & 0.96 & 0.81-1.12 & 608 & 0.97 & 0.89-1.04\end{array}$

$\begin{array}{lllllll}13 & 1.15 & 0.61-1.96 & 35 & 1.10 & 0.77-1.52\end{array}$

$\begin{array}{llllll}42 & 0.86 & 0.62-1.16 & 238 & 1.02 & 0.89-1.15\end{array}$

$\begin{array}{lllllll}70 & 0.90 & 0.71-1.14 & 337 & 1.00 & 0.89-1.10\end{array}$

$\begin{array}{lllllll}64 & 0.73 & 0.56-0.93 & 457 & 0.96 & 0.88-1.05\end{array}$

$\begin{array}{llllll}576 & 0.69 & 0.63-0.74 & 3281 & 0.80 & 0.77-0.82\end{array}$

a Carcinoma in situ lesions were excluded from all of the cancer categories.

${ }^{b}$ Excludes papillomas of the urinary organs.

c Excludes basal cell carcinoma.

d Not included in all sites. 
Table 4. Observed (0) numbers of cancer cases and the standardized incidence ratios (SIR) with their $95 \%$ confidence intervals ( $95 \% \mathrm{CI}$ ) for selected cancers among Finnish farmers in 1995-2005, by type of farm. Only cancer cases among farmers in 1978 who had the same type of farm production in 1990 or 1994 as in 1978 have been included.

\begin{tabular}{|c|c|c|c|c|c|c|c|c|c|c|c|c|c|c|c|c|c|}
\hline \multirow{3}{*}{$\begin{array}{l}\text { Primary } \\
\text { cancer } \\
\text { site }\end{array}$} & \multicolumn{17}{|c|}{ Type of farm production } \\
\hline & \multicolumn{3}{|c|}{ Crop (N=4 648) } & \multicolumn{3}{|c|}{ Beef $(N=132)$} & \multicolumn{3}{|c|}{ Dairy (N=12 388) } & \multicolumn{2}{|c|}{ Pig $(N=1271)$} & \multicolumn{3}{|c|}{ Poultry (N=537) } & \multicolumn{3}{|c|}{ Other $(\mathrm{N}=787)$} \\
\hline & 0 & SIR & $95 \% \mathrm{Cl}$ & 0 & SIR & $95 \% \mathrm{Cl}$ & 0 & $\mathrm{SIR}$ & $95 \% \mathrm{Cl}$ & $0 \mathrm{SIR}$ & $95 \% \mathrm{Cl}$ & 0 & SIR & $95 \% \mathrm{Cl}$ & 0 & SIR & $95 \% \mathrm{Cl}$ \\
\hline All si & 91 & 0.90 & 0.83 & 5 & 0.45 & 06 & 1075 & 0.82 & 6 & 1130.8 & & 56 & 0.90 & 0.6 & 85 & 0.78 & 0 \\
\hline Lip & 5 & 1.26 & $0.41-2.93$ & - & 0.00 & $0.00-53.0$ & 20 & 2.17 & $1.32-$ & 11.12 & $0.03-6.22$ & - & 0.00 & $0.00-8.19$ & 2 & 2.41 & \\
\hline Esophagus & - & 0.00 & $0.00-0.57$ & - & 0.00 & $0.00-24.8$ & 10 & 0.62 & $0.30-1.14$ & 10.61 & $0.02-3.42$ & - & 0.00 & $0.00-5.03$ & 3 & 2.59 & $0.53-7.56$ \\
\hline Colon & 24 & 0.84 & $0.54-1.24$ & - & 0.00 & $0.00-6.63$ & 41 & 0.60 & $0.43-0.82$ & 71.06 & $0.43-2.17$ & 5 & 1.53 & $0.50-3.56$ & 9 & 1.47 & $0.67-2.79$ \\
\hline Liver & 5 & 0.65 & $0.21-1.51$ & - & 0.00 & $0.00-24.3$ & 6 & 0.32 & $0.12-0.70$ & -0.00 & $0.00-2.02$ & 1 & 1.14 & $0.03-6.35$ & 1 & 0.65 & $0.02-3.63$ \\
\hline Lung & 40 & 0.53 & $0.38-0.71$ & - & 0.00 & $0.00-2.48$ & 94 & 0.51 & $0.42-0.62$ & 130.72 & $0.38-1.23$ & 5 & 0.58 & $0.19-1.34$ & 8 & 0.55 & $0.24-1.08$ \\
\hline Breast & 9 & 0.96 & $0.44-1.82$ & 1 & 4.81 & $0.12-26.8$ & 11 & 0.48 & $0.24-0.85$ & 31.79 & $0.37-5.23$ & 2 & 1.64 & $0.20-5.91$ & 2 & 0.46 & $0.06-1.65$ \\
\hline Kidney & 23 & 1.15 & $0.73-1.73$ & - & 0.00 & $0.00-8.21$ & 39 & 0.78 & $0.55-1.06$ & 51.00 & $0.32-2.32$ & - & 0.00 & $0.00-1.61$ & 2 & 0.55 & $0.07-1.97$ \\
\hline Bladder & 19 & 0.69 & $0.42-1.07$ & - & 0.00 & $0.00-7.17$ & 30 & 0.47 & $0.32-0.67$ & 71.12 & $0.45-2.30$ & 1 & 0.32 & $0.01-1.79$ & 4 & 0.71 & $0.19-1.82$ \\
\hline $\begin{array}{l}\text { Multiple } \\
\text { myeloma }\end{array}$ & 5 & 0.80 & $0.26-1.87$ & - & 0.00 & $0.00-29.9$ & 17 & 1.16 & $0.67-1.85$ & 21.39 & $0.17-5.03$ & - & 0.00 & $0.00-5.19$ & 2 & 1.51 & $0.18-5.44$ \\
\hline $\begin{array}{l}\text { Skin, basal cell } \\
\text { carcinoma }^{\text {a }}\end{array}$ & 72 & 0.67 & $0.53-0.84$ & 2 & 0.94 & $0.11-3.41$ & 180 & 0.71 & $0.61-0.81$ & 110.44 & $0.22-0.79$ & 7 & 0.58 & $0.23-1.18$ & 18 & 0.79 & $0.47-1.25$ \\
\hline
\end{tabular}

a Not included in all sites.

Table 5. Observed (0) numbers of cancer cases and the standardized incidence ratios (SIR) with their 95\% confidence intervals (95\% $\mathrm{CI}$ ) for selected cancers in 1995-2005 among the Finnish dairy farmers who had dairy production in 1978 and stayed as dairy farmers or changed the type of farm or quit farming by 1990 or 1994, by type of farm in 1990 or 1994, respectively..

\begin{tabular}{|c|c|c|c|c|c|c|c|c|c|c|c|c|c|c|c|c|c|}
\hline \multirow{3}{*}{$\begin{array}{l}\text { Primary } \\
\text { cancer } \\
\text { site }\end{array}$} & \multicolumn{14}{|c|}{ Type of farm production, 1990 or 1994} & \multirow{2}{*}{\multicolumn{3}{|c|}{$\begin{array}{l}\text { Quit farming } \\
(\mathrm{N}=59555)\end{array}$}} \\
\hline & \multicolumn{3}{|c|}{ Dairy (N=12 388) } & \multicolumn{3}{|c|}{ Crop $(N=2620)$} & \multicolumn{3}{|c|}{ Beef $(N=2029)$} & \multicolumn{3}{|c|}{ Pig $(N=251)$} & \multicolumn{2}{|c|}{ Other $(\mathrm{N}=795)$} & & & \\
\hline & 0 & SIR & $95 \% \mathrm{Cl}$ & 0 & $\operatorname{SIR}$ & $95 \% \mathrm{Cl}$ & 0 & $\operatorname{SIR}$ & $95 \% \mathrm{Cl}$ & 0 & $\operatorname{SIR}$ & $95 \% \mathrm{Cl}$ & $0 \mathrm{SIR}$ & $95 \% \mathrm{Cl}$ & 0 & $\operatorname{SIR}$ & $95 \% \mathrm{Cl}$ \\
\hline | sites & 1075 & 0.82 & $0.77-0.86$ & 354 & 0.92 & $0.83-1.02$ & 234 & 0.86 & $0.79-0.97$ & 19 & 0.83 & $0.50-1.29$ & 860.76 & $0.61-0.947$ & 7323 & 0.86 & 0.84 \\
\hline Lip & 20 & 2.17 & $1.32-3.34$ & 2 & 0.66 & $0.08-2.38$ & 3 & 1.45 & $0.30-4.24$ & - & 0.00 & $0.00-23.1$ & -0.00 & $0.00-4.26$ & 93 & 1.66 & $1.34-2.03$ \\
\hline Esophagus & 10 & 0.62 & $0.30-1.14$ & 4 & 0.97 & $0.26-2.47$ & 1 & 0.33 & $0.01-1.86$ & - & 0.00 & $0.00-12.8$ & 10.81 & $0.02-4.52$ & 64 & 0.84 & $0.64-1.06$ \\
\hline Colon & 41 & 0.60 & $0.43-0.82$ & 18 & 0.87 & $0.51-1.37$ & 8 & 0.55 & $0.24-1.07$ & 1 & 0.85 & $0.02-4.73$ & 10.16 & $0.00-0.90$ & 411 & 0.82 & $0.74-0.90$ \\
\hline Liver & 6 & 0.32 & $0.12-0.70$ & 2 & 0.36 & $0.04-1.31$ & 1 & 0.26 & $0.01-1.45$ & 1 & 3.11 & $0.08-17.3$ & 10.62 & $0.02-3.47$ & 64 & 0.60 & $0.46-0.76$ \\
\hline Lung & 94 & 0.51 & $0.42-0.62$ & 40 & 0.73 & $0.52-0.99$ & 33 & 0.87 & $0.60-1.21$ & - & 0.00 & $0.00-1.15$ & 120.76 & $0.39-1.32$ & 633 & 0.66 & $0.61-0.71$ \\
\hline Breast & 11 & 0.48 & $0.24-0.85$ & 2 & 5.61 & $0.04-1.28$ & 2 & 0.33 & $0.04-1.19$ & - & 0.00 & $0.00-10.8$ & 20.78 & $0.09-2.83$ & 706 & 0.72 & $0.67-0.77$ \\
\hline Kidney & 39 & 0.78 & $0.55-1.06$ & 10 & 0.77 & $0.37-1.42$ & 9 & 0.96 & $0.44-1.81$ & 1 & 1.11 & $0.03-6.20$ & 41.04 & $0.28-2.67$ & 260 & 0.96 & $0.85-1.08$ \\
\hline Bladder & 30 & 0.47 & $0.32-0.67$ & 22 & 1.05 & $0.66-1.58$ & 12 & 0.84 & $0.44-1.47$ & - & 0.00 & $0.00-3.32$ & 50.83 & $0.27-1.93$ & 263 & 0.71 & $0.63-0.79$ \\
\hline $\begin{array}{l}\text { Multiple } \\
\text { myeloma }\end{array}$ & 17 & 1.16 & $0.67-1.85$ & 2 & 0.45 & $0.05-1.62$ & 1 & 0.32 & $0.01-1.77$ & - & 0.00 & $0.00-14.3$ & -0.00 & $0.00-2.81$ & 101 & 0.94 & $0.76-1.13$ \\
\hline $\begin{array}{l}\text { Skin, basal cell } \\
\text { carcinoma }^{\text {a }}\end{array}$ & 180 & 0.71 & $0.61-0.81$ & 56 & 0.73 & $0.55-0.94$ & 33 & 0.61 & $0.42-0.85$ & 1 & 0.23 & $0.01-1.26$ & 190.84 & $0.50-1.301$ & 1529 & 0.81 & $0.77-0.84$ \\
\hline
\end{tabular}

a Not included in all sites.

among the dairy farmers (SIR 2.17, 95\% CI 1.32-3.34). Crop and pig farmers also had an elevated SIR value for lip cancer.

Dairy farmers in 1978 who had changed their production type to a crop had increased their risk for overall cancer from an SIR value of 0.82 to 0.92 (table 5). The SIR values for cancers of the colon, lung, and bladder were elevated by more than 0.2 for the most common cancers. A similar trend of increasing risk was shown for the dairy farmers who switched their production type to beef. The SIR value for lung cancer varied from 0.51 (95\% CI 0.42-0.62) for those who continued as dairy farmers to $0.73(95 \%$ CI $0.52-0.99)$ for those who switched to a crop and to 0.87 (95\% CI 0.60-1.21) for those who switched to beef production. Lip cancer risk showed an opposite reducing risk trend among the dairy farmers who switched farm type or quit farming.

\section{Discussion}

The cohort consisted of all farmers registered in the 31 December 1978 Farm Registry. These data contain information on the type of production of the male farmers and are considered basically reliable. The female 
farmers were classified in a more complicated way (6), and there may have been some slight misclassification in the type of farming. We also had farm type information from 31 December 1990 (or for some persons from 1994). We thus had reliable information on occupational and production type stability.

The computerized record-linkage procedures used in Finland are accurate, and the identification of the cohort members and the follow-up for incident cancer cases and vital status are virtually complete (7). Hence the results of our study are reliable. Farmers have consistently shown a decreased overall cancer risk in numerous studies (8). We also found a decreased cancer risk among Finnish farmers. The relative risk estimate (SIR) was lowest for the beef and dairy farmers, and it seemed to increase towards the level of the general population if a farmer quit farming. Retirement age seemed to be the major reason for quitting farming for the men, but the causes for quitting were less clear among the women.

However, if we look for an absolute incidence difference between the farmers and the reference population, it is similar with respect to pension ages as for working ages (ie, the strong increase in the reference incidence rate dilutes the relative difference).

Farmers have been found to have elevated rates of lip cancer (8-11). Lip cancer among Norwegian farmers was found to be associated moderately with grain production, fungal forecasts (events of wet and temperate conditions known to favor fungal growth and mycotoxin formation) and solar exposure (12). We also found elevated risks of lip cancer predominantly among the crop and dairy farmers. We did not have weather data. Microbe exposure combined with smoking and ultraviolet radiation may have been the cause of the elevated risk for lip cancer.

An elevated mortality from esophagus cancer has been shown in one study (13), and decreased mortality has been found in others (8). Elevated risks of stomach cancer have been found for agricultural workers in Brazil (13) and Italy (14), but not among farmers in the United States (15). Male farmers and female farm residents have been shown to have significantly lower mortality risks for colon cancer $(8,16,17)$. The risk of liver cancer has been below unity in many studies (8). Female agricultural workers have been found to have an increased risk for pancreas cancer in Spain (18). We found significantly reduced risks of cancers of the esophagus, colon, and liver but a rate slightly above the national average for stomach cancer. The risks of the farmers who had changed production type, from dairy farming to crop farming, or quit farming increased towards the risk of the general population. The farmers who changed their production type were somewhat older than those who kept the same production type, and this difference could explain some of the relative risk difference.
An elevated risk for sinonasal cancer has been shown for agricultural workers in orchards (19). Agricultural workers had increased mortality from laryngeal cancer in Brazil (13). Farmer applicators of herbicides and insecticides have been shown to have an elevated risk of lung cancer (20). Reduced lung cancer rates have been found among agricultural workers in numerous studies (8). Endotoxin exposure in agricultural work has been suggested as the reason (21). We did not find excesses of cancer of the nose or nasal sinuses, and the incidence of laryngeal and lung cancers was significantly reduced. Lung cancer risk was lowest among the dairy farmers and increased if the dairy farmer quit farming or changed the type of farming. This finding supports the theory of cancer-protective effects of endotoxins. It is also known that Finnish farmers, and particularly women in the countryside, especially in earlier times, smoked less than Finns on the average (22). Farmers leaving dairy farming may contract a more urban lifestyle.

Breast cancer has been found to be associated with pesticide use on farms in some studies (23), but not in others (24). We found a significantly reduced risk for breast cancer that could be attributable to the greater number of children among the farmers (25). However, the incidence of other cancers related to low parity (endometrial and ovarian cancers) was not reduced, and therefore other factors, such as the protective effect of physical activity, may explain the low breast cancer incidence (25). The SIR value for cervical cancer was significantly low in the oldest birth cohorts but exceeded 1.0 for the current farmers. This finding may reflect the change in sexual behavior to a more liberal direction in rural areas.

Elevated standardized incidence ratios for prostate cancer have been found for farmers in several countries $(8,26,27)$. Farm workers with relatively high exposures to organochlorine pesticides, organophosphate pesticides, fumigants, or triazine herbicides have shown elevated risks of prostate cancer when compared with workers with lower levels of exposure $(28,29)$. We did not find any elevated risks for prostate cancer. The incidence of prostate cancer is heavily linked to the frequency of prostate-specific antigen (PSA) tests. If the frequency is markedly lower among farmers than among other Finnish men, then their SIR value of 0.97 can be interpreted as an excess risk. There is no data on the PSA testing of farmers in Finland.

The risk of kidney cancer among farmers has been significantly decreased in some studies (8). An elevated risk for bladder cancer has been shown for female field crop and vegetable farm workers (30). We found reduced risks of kidney and bladder cancer.

Low incidence and mortality rates for skin melanoma (16), but excesses for nonmelanoma skin cancer $(8,9,31)$, have been shown for male farmers. We did 
not observe excesses of skin cancer among Finnish farmers. On the contrary, basal cell carcinoma risk was significantly reduced. This finding may reflect a lower than average diagnostic activity among the farmers. However, another indicator of low diagnostic activity, incidence of spread tumors with an unknown primary site, showed low rates. We believe that the Finnish medical care system offers similar diagnostic possibilities for farmers and other Finns.

Farmers and farm workers have been shown to have an elevated glioma incidence in some studies (32) but not in others $(33,34)$. Mortality from brain cancer was elevated among French farmers, and it was associated with pesticide use (35). An elevated risk of brain cancer was also found for Italian dairy farmers (36). We did not find excesses of cancers of the nervous system. The previous finding of an elevated risk of soft tissue sarcoma (9) did not gain support in our study either.

An excess of non-Hodgkin's lymphoma has been found for farmers (37) and has been suggested to be attributable to exposure to pesticides (38). Pesticides (39) and certain animal viruses (40) may also be involved in the excess myeloma risk observed in several farmer cohorts (8-10), and glyphosate has been suggested to be associated with the incidence of multiple myelomas for pesticide applicators (41). Farmers have been found to have excesses of leukemia $(8,9,39)$. Exposure to pesticides has been suggested to increase the risk for leukemia (38). We did not find excesses of cancers of the hematopoetic system. It may be that the excess cancer risks found in previous studies were not replicated in our study because of less use of pesticides and other chemicals on Finnish farms.

The results for overall cancer and lip cancer were similar in comparison with those of a previous study based on the same cohort with an earlier follow-up time (1979-1993). Farmers with animals had lower cancer rates than crop farmers in both studies.

In conclusion, the cancer incidence of Finnish farmers was significantly below the national average. The only cancer site with a markedly increased risk was lip cancer. The finding that lung cancer risk was low among dairy farmers but increased with a change to another type of farm production gives some support to the hypothesis that endotoxin exposure may decrease cancer risk.

\section{References}

1. Eurostat. Agricultural statistics. Luxembourg: Eurostat; 2007.

2. International Agency for Research on Cancer (IARC). Overall evaluations of carcinogenicity to humans. Lyon: IARC; 2005.

3. Andersen A, Barlow L, Engeland A, Kjærheim K, Lynge E,
Pukkala E. Work-related cancer in the Nordic countries. Scand J Work Environ Health. 1999;25 suppl 2:1-116.

4. Mastrangelo G, Grange JM, Fadda E, Fedeli U, Buja A, Lange JH. Lung cancer risk: effect of dairy farming and the consequence of removing that occupational exposure. Am J Epidemiol. 2005;161(11):1037-46.

5. Pukkala E, Notkola V. Cancer incidence among Finnish farmers, 1979-93. Cancer Causes Control. 1997;8(1):25-33.

6. Notkola VJ, Husman KR. Mortality among female farmers in Finland in 1979-1985. Scand J Soc Med. 1988;16(3):18791.

7. Teppo L, Pukkala E, Lehtonen M. Data quality and quality control of a population-based cancer registry: experience in Finland. Acta Oncol. 1994;33(4):365-9.

8. Blair A, Zahm SH. Cancer among farmers. Occup Med. 1991;6(3):335-54.

9. Blair A, Zahm SH. Agricultural exposures and cancer. Environ Health Perspect. 1995;103 suppl 8:205-8.

10. Wiklund K, Dich J. Cancer risks among male farmers in Sweden. Eur J Cancer Prev. 1995;4(1):81-90.

11. Lindqvist $\mathrm{C}$. Risk factors in lip cancer: a questionnaire survey. Am J Epidemiol. 1979;109(5):521-30.

12. Nordby KC, Andersen A, Kristensen P. Incidence of lip cancer in the male Norwegian agricultural population. Cancer Causes Control. 2004;15(6):619-26.

13. Meyer A, Chrisman J, Moreira JC, Koifman S. Cancer mortality among agricultural workers from Serrana Region, state of Rio de Janeiro, Brazil. Environ Res. 2003;93(3):264-71.

14. Bucchi L, Nanni O, Ravaioli A, Falcini F, Ricci R, Buiatti E, et al. Cancer mortality in a cohort of male agricultural workers from northern Italy. J Occup Environ Med. 2004;46(3):249 56.

15. Lee WJ, Lijinsky W, Heineman EF, Markin RS, Weisenburger DD, Ward MH. Agricultural pesticide use and adenocarcinomas of the stomach and oesophagus. Occup Environ Med. 2004;61(9):743-9.

16. Hanrahan LP, Anderson HA, Haskins LK, Olson J, Lappe K, Reding D. Wisconsin farmer cancer mortality, 1981 to 1990: selected malignancies. J Rural Health. 1996;12(4 Suppl):2737.

17. Wang Y, Lewis-Michl EL, Hwang SA, Fitzgerald EF, Stark AD. Cancer incidence among a cohort of female farm residents in New York State. Arch Environ Health. 2002;57(6):561-7.

18. Alguacil J, Porta M, Benavides FG, Malats N, Kogevinas M, Fernandez E, et al. Occupation and pancreatic cancer in Spain: a case-control study based on job titles: PANKRAS II Study Group. Int J Epidemiol. 2000;29(6):1004-13.

19. Leclerc A, Luce D, Demers PA, Boffetta P, Kogevinas M, Belli S, et al. Sinonasal cancer and occupation: results from the reanalysis of twelve case-control studies. Am J Ind Med. 1997;31(2):153-65.

20. Alavanja MC, Dosemeci M, Samanic C, Lubin J, Lynch CF, Knott C, et al. Pesticides and lung cancer risk in the agricultural health study cohort. Am J Epidemiol. 2004;160(9):876-85.

21. Lange JH. Reduced cancer rates in agricultural workers: a benefit of environmental and occupational endotoxin exposure. Med Hypotheses. 2000;55(5):383-5.

22. Berg M-A, Peltoniemi J, Puska P. Health behavior among Finnish adult population. Helsinki: Finnish National Public Health Institute; 1992.

23. Band PR, Le ND, Fang R, Deschamps M, Gallagher RP, Yang P. Identification of occupational cancer risks in British Columbia: a population-based case-control study of 995 incident breast cancer cases by menopausal status, controlling for confound- 
ing factors. J Occup Environ Med. 2000;42(3):284-310.

24. Engel LS, Hill DA, Hoppin JA, Lubin JH, Lynch CF, Pierce $\mathrm{J}$, et al. Pesticide use and breast cancer risk among farmers' wives in the agricultural health study. Am J Epidemiol. 2005;161(2):121-35.

25. Rintala PE, Pukkala E, Paakkulainen HT, Vihko VJ. Self-experienced physical workload and risk of breast cancer. Scand J Work Environ Health. 2002;28(3):158-62.

26. Sharma-Wagner S, Chokkalingam AP, Malker HS, Stone BJ, McLaughlin JK, Hsing AW. Occupation and prostate cancer risk in Sweden. J Occup Environ Med. 2000;42(5):517-25.

27. Parker AS, Cerhan JR, Putnam SD, Cantor KP, Lynch CF. A cohort study of farming and risk of prostate cancer in Iowa. Epidemiology. 1999;10(4):452-5.

28. Settimi L, Masina A, Andrion A, Axelson O. Prostate cancer and exposure to pesticides in agricultural settings. Int J Cancer. 2003;104(4):458-61.

29. Mills PK, Yang R. Prostate cancer risk in California farm workers. J Occup Environ Med. 2003;45(3):249-58.

30. Mannetje A, Kogevinas M, Chang-Claude J, Cordier S, Gonzalez CA, Hours M, et al. Occupation and bladder cancer in European women. Cancer Causes Control. 1999;10(3):209-17.

31. Pukkala E. Cancer risk by social class and occupation: a survey of 109,000 cancer cases among Finns of working age. Heidelberg (Germany): Karger; 1995.

32. De Roos AJ, Stewart PA, Linet MS, Heineman EF, Dosemeci $\mathrm{M}$, Wilcosky T, et al. Occupation and the risk of adult glioma in the United States. Cancer Causes Control. 2003;14(2):13950 .

33. Menegoz F, Little J, Colonna M, Arslan A, Preston-Martin S, Schlehofer B, et al. Contacts with animals and humans as risk factors for adult brain tumours: an international case-control study. Eur J Cancer. 2002;38(5):696-704.
34. Schlehofer B, Hettinger I, Ryan P, Blettner M, Preston-Martin $\mathrm{S}$, Little J, et al. Occupational risk factors for low grade and high grade glioma: results from an international case control study of adult brain tumours. Int J Cancer. 2005;113(1):11625 .

35. Viel JF, Challier B, Pitard A, Pobel D. Brain cancer mortality among French farmers: the vineyard pesticide hypothesis. Arch Environ Health. 1998;53(1):65-70.

36. Mastrangelo G, Marzia V, Marcer G. Reduced lung cancer mortality in dairy farmers: is endotoxin exposure the key factor? Am J Ind Med. 1996;30(5):601-9.

37. Keller-Byrne JE, Khuder SA, Schaub EA, McAfee O. A metaanalysis of non-Hodgkin's lymphoma among farmers in the central United States. Am J Ind Med. 1997;31(4):442-4.

38. Miligi L, Costantini AS, Bolejack V, Veraldi A, Benvenuti A, Nanni O, et al. Non-Hodgkin's lymphoma, leukemia, and exposures in agriculture: results from the Italian multicenter case-control study. Am J Ind Med. 2003;44(6):627-36.

39. Kristensen P, Andersen A, Irgens LM, Laake P, Bye AS. Incidence and risk factors of cancer among men and women in Norwegian agriculture. Scand J Work Environ Health. 1996;22(1):14-26.

40. Baris D, Silverman DT, Brown LM, Swanson GM, Hayes RB, Schwartz AG, et al. Occupation, pesticide exposure and risk of multiple myeloma. Scand J Work Environ Health. 2004;30(3):215-22.

41. De Roos AJ, Blair A, Rusiecki JA, Hoppin JA, Svec M, Dosemeci M, et al. Cancer incidence among glyphosate-exposed pesticide applicators in the agricultural health study. Environ Health Perspect. 2005;113(1):49-54.

Received for publication: 28 June 2007 